\title{
Tarihi Okul Yapılarında Isıl Konfor Gereksinimleri Bağlamında Enerji İyileştirme Stratejileri: Ulugazi İlköğretim Okulu
}

\author{
Mohammed S.G. ABUSAMHADANA ${ }^{1}$, Neslihan TÜRKMENOĞLU BAYRAKTAR ${ }^{2}$
}

Öz

Bu çalışmada İzmit Ulugazi İlköğretim Okulu'nda enerji verimliliği ve ısıl konforu arttırma amacıyla gerçekleştirilebilecek iyileştirme stratejileri incelenmiştir. Tarihi niteliğe sahip yapılarda gerçekleştirilecek müdahalelerin yapının özgün kimlik unsurlarına, tarihi, estetik değerine olumsuz etkide bulunmayacak düzeyde olması gerektiğinden, uygulamaya yönelik seçenekler, tarihi ve tarihi niteliğe sahip olmayan yapı tipleri özelinde farklılaşmalıdır. Bu bağlamda İzmit Ulugazi İlköğretim Okulu farklı zamanlarda inşa edilmiş 3 yapıdan oluşmakla birlikte, müdahale önerileri sadece tarihsel değere sahip olan ve 1932 yılında Kocaeli Valisi Eşref Seyit Bey tarafından Müteahhit Haşim Bey'e inşa ettirilen ana blok özelinde ele alınmıştır. Yapılarda enerji verimliliğini arttırmaya yönelik iyileştirme seçeneklerinin belirlenmesinde ilk aşama yapıların mevcut fiziksel koşullarının ve enerji tüketim biçim ve miktarlarının belirlenme sürecidir. Bu sebeple tarihi yapı bloğunda mevcut enerji tüketim miktarlarının değerlendirilebilmesi için 2014-2015 yıllarına ait aylık doğalgaz faturaları elde edilmiştir. Isıtma sistemlerinin verimliliği, işletim biçimleri, yapı kabuğunun fiziksel koşulları ve dış iklimsel parametrelerin bileşik etkisi altında oluşan iç ortam iklimsel şartları belirlemek üzere zemin katta, güney yönünde konumlanan örnek sınıfta sıcaklık, nem, iç hava hareketi hızı ölçümleri gerçekleştirilmiştir. Ölçümlerle eşzamanlı uygulanan, öğrenci ve öğretmenlerin katıldığı anket çalışmalarıyla, kullanıcıların iç ortam iklimsel koşullardan memnuniyet dereceleri değerlendirilmiştir. Ulugazi İlköğretim okulu ana bloğu için yapılan literatür araştırması ile ölçüm ve anketlerden elde edilen veriler doğrultusunda belirlenen yapı kabuğu ve mekanik sistemlerde uygulanabilecek müdahale seçenekleri ele alınmıştır.

\section{Energy Refurbishment Strategies within the framework of Thermal Comfort Requirements for Historic School Buildings}

\begin{abstract}
\footnotetext{
${ }^{1}$ Kocaeli Üniversitesi, Fen Bilimleri Enstitüsü, Mimarlık Anabilim Dalı, İzmit, Kocaeli, Türkiye

${ }^{2}$ Kocaeli Üniversitesi, Mimarlık ve Tasarım Fakültesi, Mimarlık Bölümü, İzmit, Kocaeli, Türkiye İlgili Yazar / Corresponding Author: neslihanturkmenoglu@gmail.com

Gönderim Tarihi: 31.10 .2018

Kabul Tarihi: 25.12.2018
}

In this study, refurbishment strategies for improving energy efficiency and thermal comfort in Izmit Ulugazi Primary School were investigated. Since the interventions to be carried out in historical buildings must be at a level that does not have a negative effect on the original identity elements, historical and aesthetic value and application-oriented strategies should be differentiated for the building types that are historical or vise versa. In this context, although Izmit Ulugazi Primary School consists of 3 buildings constructed at different times, the intervention proposals are handled only for the main block which was built to contractor Haşim Bey by the Governor of Kocaeli Eşref Seyit Bey in 1932. The first step in determining the refurbishment strategies for increasing energy efficiency in buildings is the process of 
determining the current physical conditions of buildings and the types and forms of energy consumption. For this reason, in order to evaluate the current energy consumption amounts and forms in the historical building block, the monthly natural gas bills of the years 2014-2015 are obtained. Temperature, humidity, internal air movement velocity measurements are carried out in the sample class that is located on the south of the ground floor in order to determine the efficiency of the heating systems, the operating conditions, the physical conditions of the building envelope and the indoor climatic conditions formed under the combined effect of the external climatic parameters. The results of the survey process, applied concurently with the measurement campaign are, evaluated in order to examine the satisfaction level of the students and the teachers by the indoor climatic conditions. Strategies for building envelope and mechanical systems are discussed within the context of the data obtained by the survey and measurement process and the literature review for the main historic block of the Ulugazi Primary School

Keywords: Energy Refurbishment, Thermal Comfort, Historical School Buildings

\section{GíRiş}

Yenilenemeyen enerji kaynaklarının neden olduğu hava kirliliği, enerji tüketiminin gün geçtikçe artışı, ithal edilen enerji kaynaklarının maliyetlerinin yükselmesi gibi sorunlar tüm dünyada olduğu gibi Türkiye'de de her alanda yenilenebilir enerji kaynaklarının kullanımına yönelimi arttırmakta ve mevcut kaynakların etkin kullanımına yönelik stratejiler üretilmesini zorunlu kılmaktadır. Tüm sektörleri ilgilendiren ortak problemler ve çözüm arayışları yaşam dönemlerinin tümünde büyük enerji kayıplarından ve karbon salınımlarıyla çevresel olumsuz etkilerden sorumlu olan yapı sektörü için de söz konusudur. Toplam karbon salınımlarının \%40'ı ve birincil enerji kaynakları tüketiminin yine \%40'ı tek başına yapı sektöründen kaynaklanır (Berardi, 2015, s.129). Yapılarda enerji tüketimi yaşam dönemi boyunca üretim, inşaat malzemelerinin taşınması, inşa, işletim ve yıkım süreçlerinin tümünde farklı oranlarda gerçekleşmektedir. Yeni inşa edilecek yapıların yanı sıra önemli bir ağırlığa sahip mevcut yapılarda da enerji verimliliğinin arttırılması zorunlu bir yaklaşım haline gelmiştir. Mevcut yapı stoğu konut binalarının yanı sıra kamusal ya da özel teşebbüsle inşa edilmiş hastane, okul, kültür merkezi, vs. gibi işlevlere sahip yapı tiplerini kapsar. Okullar ticari merkezler ve hastanelerden sonra ve enerji tüketiminin en fazla gerçekleştiği yapı tipleri olduğundan, enerji verimliliğinin arttırılmasına yönelik müdahaleler ekonomik ve çevresel koşullara büyük oranda katkı sunar (Somyürek U, 2017, s.2)

Tasarım aşamasında fiziksel çevre etkenlerinin çoğunlukla inmal edilmesi nedeniyle enerji kayıplarının ve yapısal bozulmaların çokça rastlandığı okul yapılarında gerçekleştirilen müdahaleler enerji verimliliğini arttırmanın yanında öğrencilerin iklimsel, görsel konfor gereksinimleri doğrultusunda daha uygun koşullara sahip, sağlıklı mekânlarda eğitim öğretim hayatlarına devam etmelerine imkân sağlayacaktır. Maliyet, enerji verimliliğine katkı, uygulama kolaylığı ekseninde yapı kabuğunda, elektrik ve mekanik sistemler için gerçekleştirilen müdahaleler ve alternatif yenilenebilir enerji kaynaklarının kullanımına dayalı aktif sistemlerin entegrasyonu gibi uygulamalar enerji verimliliğini arttırma sürecinde öne çıkan yaklaşımlardır. Uygulanacak stratejiler tarihi değere sahip yapılarla, tarihi değere sahip olmayan mevcut yapılar arasında değişim gösterir. Tarihi yapıları günümüz koşullarına uymadığı ya da gereksinimlerini karşılayamadığı varsayımıyla görmezden gelmek ya da sürdürülebilirliklerini engelleyen koşulları ortadan kaldırmak üzere gerekli girişimlerde bulunmamak toplumsal bellekteki önemli izleri de yok edecektir. Bu yapılar yeni ya da özgün işlevleriyle sürekli gözlem, bakım ve onarım faaliyetleriyle korunarak ait oldukları toplumun yeni bilgi ve araçlara dayanan gelişimini yansıtmaya devam etmelidir. 
Koruma amacıyla tarihi yapıların onarılması ve günümüz kriterlerine göre kullanıma daha uygun hale getirilmesi birçok bileşene bağlı karmaşık bir süreçtir. Tarihi binaları koruma süreci dış cepheye yönelik estetik değerleri gözeterek, iç mekân estetiği, işlevsel unsurlar, taşıyıcı sistem, sağladıkları görsel, iklimsel ve akustik konfor koşullar, enerji tüketim şekil ve miktarları gibi tüm bileşenler ve kullanım süreçleriyle birlikte ele alınarak kapsamlı olarak gerçekleşebilir (Milone, Peria, Pitruzzella, Rizzoa, 2015, s.8; Ascione, Biancoa, Masia, Rossib, Vanoli, 2015, s.173). Tarihi yapılarda önemli bir kimlik unsuru olan cephe özelliklerinin yapılacak müdahalelerle bozulma riski nedeniyle diğer yapı tipleri için uygulanabilecek stratejilerin tümünün gerçekleştirilmesi mümkün olamamaktadır. Bu sebeple uygun stratejilerin belirlenmesinde yapıya dair mevcut fiziksel koşulların ve kullanıcıların yapının sunduğu konfor koşullarına ilişkin memnuniyet seviyelerinin belirlemesi önemli bir aşamayı oluşturur.

Çalışmada okul yapılarında enerji tüketimini azaltmak, enerji tüketimini yenilenebilir enerji kaynaklarına dayandıracak ve aynı zamanda okul kullanıcıları olarak öğrenciler ve eğitimcilerin konfor koşulları altında eğitim süreçlerine devam etmelerini sağlamak üzere uygulanabilecek enerji iyileştirme stratejileri, İzmit'in toplumsal belleğinde önemli bir yer tutan Ulugazi Illköğretim Okulu bünyesinde, tarihi niteliğe sahip yapı bloğu üzerinden ele alınmıştır. Stratejilerin önerilmesinde göz önüne alınması gerekli olan yapıya dair mikro iklimsel koşullar, kullanıcıların memnuniyet seviyeleri iç ve dış ortamda gerçekleştirilen sıcaklık, nem, hava hareketi hızı ölçümleri ve eşzamanlı olarak öğrenci ve öğretmenlerin katılımıyla uygulanan anket çalışmalarıyla belirlenmiştir. Bu bağlamda yapı kabuğu ve mevcut mekanik sistemler için uygulanabilecek enerji verimliliğini ve iç ortam iklimsel konfor koşullarını iyileştirmeye yönelik yaklaşımlar önerilmiştir.

\section{ULUGAZI ILKÖĞRETIM OKULU'NDA MEVCUT ISITMA AMAÇLI ENERJI TÜKETIMLERI, MIKKROIKLIMSEL KOŞULLAR VE ETKILERI}

Kocaeli İli'nin İzmit İlçesi'nde yer alan Ulugazi İlköğretim Okulu 3 ayrı yapıdan oluşur (Şekil1). Çalışmada ele alınan tarihi kısım olan A Blok 1932 yılından günümüze kadar geçen uzun sürece rağmen hala özgün eğitim yapısı olma işlevini devam ettirmektedir. "Cumhuriyet'in kuruluşundan 1930'lu yılların başına kadar olan bir süreçte ülkemizde inşa edilen pek çok kamu yapısında görüldüğü üzere; batılı tasarım anlayışı ve yapım teknikleriyle (betonarme karkas sistemi dikdörtgen pencere tasarımı, vs.) Osmanlı-Türk mimarisine ait tarihi öğeleri (simetrik cephesi, merdivenli girişi, kırma çatı kullanımı, saçakları ve çatı payandaları, kat silmeleri, vs.) birleştiren bir 'milli mimarlık' üslubuyla inşa edilen yapı, taşra kentlerinde bu anlayışın uygulandığı ilk örneklerden birini teşkil etmekte ve bu kimliğiyle de mimarlık tarihimiz ve İzmit bağlamında kültürel ve tarihi bir değer taşımaktadır (Şener, s.205).

Yakın tarihlerde ancak farklı zaman dilimlerinde inşa edilen diğer iki yapıyla birlikte Ulugazi İlköğretim Okulu tarihi yapılarda uygulanabilecek iyileştirme stratejilerinin değerlendirilmesi için özgün bir örnek oluşturur. Çünkü ısıl çevre, enerji tüketim miktarları, enerji, iklimsel, görsel ve akustik konfor gereksinimleri doğrultusunda yenileme ölçütleri her blok için farklılık göstermektedir. Ancak çalışma kapsamında sadece tarihi blok için uygulanabilecek stratejiler belirlenmiştir. 

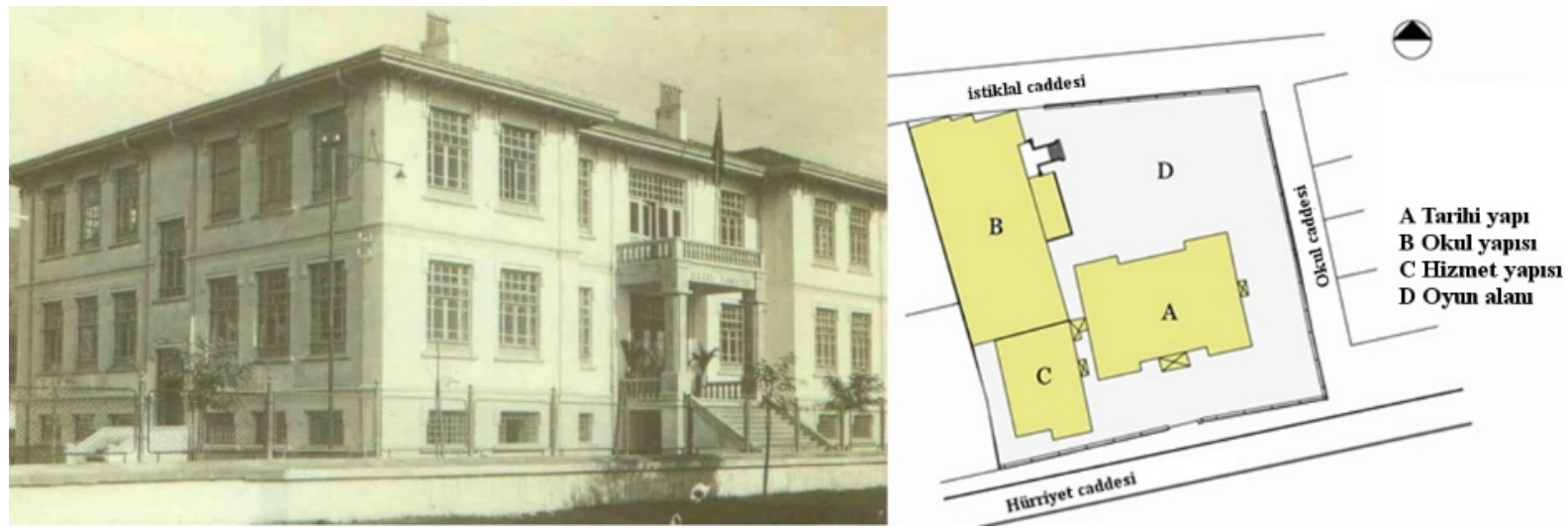

Şekil 1: Ulugazi İlköğretim okulu tarihi yapı bloğu cepheleri ve arazideki konumu. URL: http://ulugazi.meb.k12.tr/meb_iys_dosyalar/41/01/315404/icerikler/okulumuzuntarihcesi_274194 .html

Ulugazi İlköğretim Okulu'nda bulunan söz konuğu tarihi bloğa ait enerji tüketim miktarları ve öğrencilerin iç iklimsel koşullardan memnuniyet dereceleri araştırılmıştır. Öncelikle yapının aylık doğalgaz tüketimi değişimleri ilgili kurumdan elde edilen doğalgaz faturalarıyla ortaya konulmuş, tüketimlerin artış gösterdiği, riskli dönemler belirlenmiştir.

Zemin katta, güney yönünde konumlanan sınıfta Mayıs 2014 tarihinde, mevcut iç ortam mikro iklimsel koşulların ortaya konulması amacıyla iç ve dış ortam hava sıcaklığı, bağıl nem ve iç hava hareketi hızı gibi iklimsel parametrelere yönelik ölçümler gerçekleştirilmiştir. Öğrenciler ve öğretmenlerin iç ortam mikro iklimsel koşullardan memnuniyet derecelerini belirlemek üzere ölçümlerle eşzamanlı olarak anket uygulaması yapılmıştır. Tüm adımlardan elde edilen veriler çerçevesinde tarihi blokta enerji verimliliğinin ısı konfor koşulları göz önüne alınarak arttırılması için uygun iyileştirme ölçütleri belirlenmiştir.

\subsection{Ulugazi İlköğretim Okulu’nda Aylık Enerji Tüketimi}

Ulugazi Okulu'nda Güz ve Bahar dönemleri boyunca günde 10 saat süre ile eğitim verilmektedir. Yaz dönemini kapsamayan bu uzun süreç okulda büyük bir ölçüde ısıtma, aydınlatma ve iklimlendirme için enerji intiyacı doğurmaktadır. 2014-2015 eğitim ve öğretim yılı için İzmit Bölgesi ilgili kurumları olarak İzgaz'dan elde edilen (ŞubatMayıs 2014 ve Kasım-Aralık 2015-) faturalar vasıtasıyla aylık doğalgaz tüketim miktarları belirlenmiştir. Doğalgaz tüketiminin gerçekleştiği aylar karşılaştıııldığında gaz tüketiminin en fazla mart ve aralık aylarında gerçekleştiği görülür. Şubat ayında enerji tüketim miktarı $(26024 \mathrm{~kW} / \mathrm{h})$ iken Kasım ayında $(29660 \mathrm{~kW} / \mathrm{h})$ olarak gerçekleşmiştir(Şekil 2). 


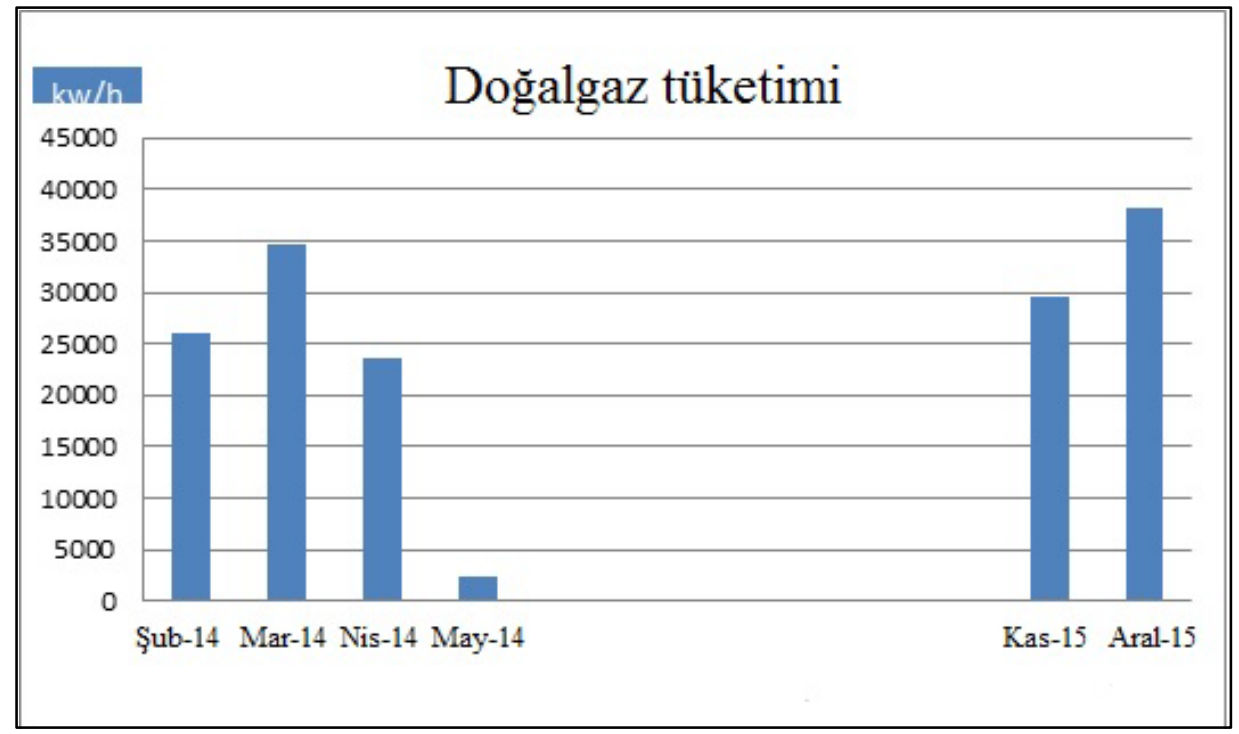

Şekil 2:. 2014-2015 döneminde doğal gaz tüketimi miktarlarının aylara göre değişimi

\subsection{Mikro Íklimsel Koşullar}

Ulugazi İlkokulu'na ait tarihi yapıda iklimsel koşullara ait parametrelerin değişimlerini, büyüklüklerini ve etki derecelerini incelemek üzere iç, dış sıcaklık, bağıl nem ve iç hava hareketi hızı ölçümleri gerçekleştirilmiştir.

Zemin katta, güney yönünde yer alan sınıfa yerleştirilen EXTECH RHT10 Nem Sıcaklık Veri Kayıt Cihazı (datalogger) ile Mayıs 2014 ayı süresince 10 saniyelik aralıklarla iç ortam sıcaklık ve nem değişimleri kayıt alınmıştır (Şekil3).

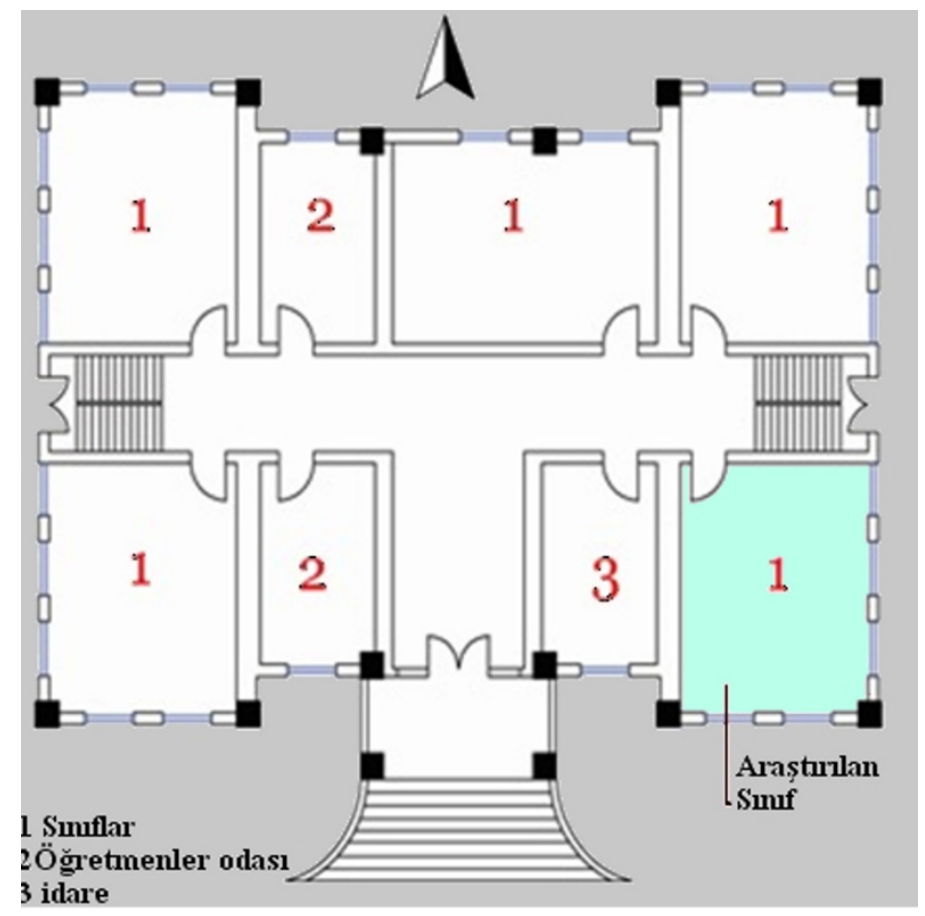

Şekil 3: Zemin katta güney yönünde sıcaklık, nem veri kaydedicisinin yerleştirildiği sınıf 
Eş zamanlı olarak okul dışında güney yönünde konumlandırılan farklı bir sıcaklık nem veri kaydedicisiyle de dış ortam sıcaklık ve nem verileri elde edilmiştir. Tablo 1'de okul dışında ve sınıfta ölçülmüş saatlik sıcaklık ve nem verilerinin anket sürecine denk gelen zaman aralıkları değerleriyle hesaplanan minimum, maksimum ve ortalama değerler görülmektedir.

Tablo 1.Okul dışında ve sınıf içinde anket çalışmasının olduğu zaman aralığında ortalama sıcaklık ve nem değerleri

\begin{tabular}{|l|c|c|}
\hline \multicolumn{1}{|c|}{ Yer } & Sırin & Dışarısı \\
& Tarih $(5 / 5 / 2014)$ & Tarih (5/5/2014) \\
& Saat $(10: 45-11: 14)$ & Saat (11:45- 12:15) \\
\hline Sıcaklık $\left({ }^{\circ} \mathrm{C}\right)$ & & 24,1 \\
Maximum & 27,9 & 21,4 \\
Minimum & 25,2 & 22,3 \\
Ortalama & 26,32 & \\
Bağıl Nem (\%) & & 73,4 \\
Maximum & 53,6 & 61,8 \\
Minimum & 59,8 & 64 \\
Ortalama & & \\
\hline
\end{tabular}

Sınıftaki hava akımlarına yönelik hız değişkenini ölçmek üzere CFM/CMM ThermoAnemometer AN100 marka anemometre kullanılmıştır. Sabah ve öğleden sonra gerçekleştirilen ölçümlerde iç ortam hava hareketi hız değerleri sınıftaki 24 sıranın yanında ayakta, ölçülmüştür. Ancak elde edilen değerlerin tümünün sıfıra yakın değer aralıklarında, çok küçük hızlarda gerçekleştiği görülmüştür.

\subsection{Isıl Konfor Koşullarına Yönelik Veriler}

Sınıf ortamında öğrencilerin öğrenme süreçlerindeki performanslarını ve sağlığını etkileyen iklimsel konfor parametrelerinin aldığı değerleri ölçmek ve değerlendirmek üzere eşzamanlı anket ve ölçüm çalışmaları gerçekleştirilmiştir. Ankette öğrencilerin yaş ve buna bağlı farkındalık seviyeleri, öğretmenlerin önerileri göz önüne alınmıştır. Anket sorularını sabah ve öğleden sonra saatlerinde 20'şer öğrenci cevaplamıştır. Öğrencilerin iç ortam iklimsel şartları algılama biçimlerinin, koşullardan memnuniyet miktarlarının ve iklimsel koşulların değişimine yönelik tercihlerinin Ashrae 2005' de tanımlanan Fanger ölçeği kapsamında belirlenmesi hedeflenmiştir (Ashrae 2005, s.11). Yaklaşıma göre $[-1,0,1]$ arası oylar normal koşulları ifade ederken $[-3,-2]$ ve $[3,2]$ arası oylar memnuniyetsizlik belirten aralıktır (Fanger, 1973, s.322).

Tablo 2 öğrencilerin sınıflardaki ısı koşullara yönelik oylarını ve her koşul için cevap yüzdelerini göstermektedir. Tablodan görülebileceği gibi, öğrencilerin sınıftaki konumlarına bağlı olarak iklimsel koşullardan etkilenme durumları değişim göstermektedir. Pencere kenarında oturan öğrencilerin çoğu pencerelerden güneş 
kazanımları yüksek olduğu için iç ortam iklimsel koşullarını sıcak veya ılık olarak değerlendirirken diğer öğrenciler ortamı iklimsel açıdan rahat, serin ya da soğuk olarak tanımlamışlardır.

Tablo 2. Isıl duyum derecelerinin değişimi

\begin{tabular}{|c|c|c|c|c|c|c|c|}
\hline & $(-3)$ & $(-2)$ & $(-1)$ & $(0)$ & $(1)$ & $(2)$ & $(3)$ \\
& Soğuk & Serin & Az serin & Rahat & Az Ilık & Ilık & Sıcak \\
\hline Oylar & $2(10 \%)$ & $2(20 \%)$ & $1(5 \%)$ & $4(15 \%)$ & $1(5 \%)$ & $4(20 \%)$ & $6(30 \%)$ \\
\hline
\end{tabular}

Tablo 3. öğrencilerin ısıl koşullardan memnuniyet seviyelerini ve her durum için cevapların dağılımını göstermektedir. Tablodan görülebileceği gibi, öğrencilerin çoğunluğu sınıftaki ısıl koşullardan memnun değildir.

Tablo 3..Öğrencilerin ısıl koşullardan memnuniyet dereceleri ve her durum için cevapların sayısı, yüzdesi

\begin{tabular}{|c|c|c|c|c|c|c|c|}
\hline & $(-3)$ & $(-2)$ & $(-1)$ & $(0)$ & $(1)$ & $(2)$ & (3) \\
& $\begin{array}{c}\text { Çok } \\
\text { memnun }\end{array}$ & Memnun & $\begin{array}{c}\mathrm{Az} \\
\text { memnun }\end{array}$ & ok & $\begin{array}{c}\mathrm{Az} \\
\text { memnuniye } \\
\text { tsiz }\end{array}$ & Memnuniyetsiz & $\begin{array}{c}\text { Çok } \\
\text { memnuniyetsiz }\end{array}$ \\
\hline Oylar & $1(5 \%)$ & $2(10 \%)$ & $3(15 \%)$ & $3(15 \%)$ & $2(10 \%)$ & $4(20 \%)$ & $5(25 \%)$ \\
\hline
\end{tabular}

Tablo 4'te sınıfta gerçekleştirilen anket sonucunda ısıl konfor koşullarının değişimi konusunda beklentiler görülmektedir.

Tablo 4 Isıl koşullara yönelik tercih ölçeği

\begin{tabular}{|c|c|c|c|}
\hline & Daha ılık & Değiş̧im yok & Daha soğuk \\
\hline Sınıf & $1(5 \%)$ & $8(40 \%)$ & $11(55 \%)$ \\
\hline
\end{tabular}

EN15251 standardına göre ısıtma döneminde sınıflarda sıcaklıklar $20-24{ }^{\circ} \mathrm{C}$ arasında tutulmalıdır (Trachte, 2015, s.39). Çünkü $24^{\circ} \mathrm{C}$ üzerindeki iç ortam sıcaklıkları eğitim ve öğretim süreçlerini olumsuz şekilde etkilemektedir. İncelenen sınıfta ölçülen $26-32^{\circ} \mathrm{C}$ arasındaki sıcaklıklar Tablo 5'de verilen değerlere göre optimum sıcaklık değerlerinin üzerindedir. Anket sonuçları da karşılaştırıldığında Şekil 4'de de görüldüğü gibi öğrencilerin çoğunluğu sınıfın sıcak olduğunu belirtmiştir. Şekil 5' de büyük bir öğrenci oranının bu koşullardan memnuniyetsizliğini ortaya koymaktadır. Öğrencilerin çoğunluğu iç ortamı sıcak ve konforsuz olarak nitelemiştir. Çalışma süresi boyunca öğrencilerin ince kıyafetler giyerek sıcak iç koşullara adaptasyon sağlamaya çalışmaları da bu durumu desteklemektedir. Anketteki değerler öğrencilerin daha serin bir ortamda olma arzusunda olduğunu ve tavsiye edilen sıcaklık değeri olan $\left(24^{\circ} \mathrm{C}\right)^{\prime} y e$ ulaşmanın gereğini ortaya koymaktadır. Bu sıcak ortam ve buna bağlı memnuniyetsizlik pencerelerden etkiyen direkt güneş ışınımı ve radyatörlerden kaynaklanan fazla ıSı 
kazanımları nedeniyle oluşmaktadır. $\mathrm{Bu}$ da bu etkilerle oluşan istenmeyen ısı kazanımlarının azaltılması gerekliliğini ortaya koymaktadır.

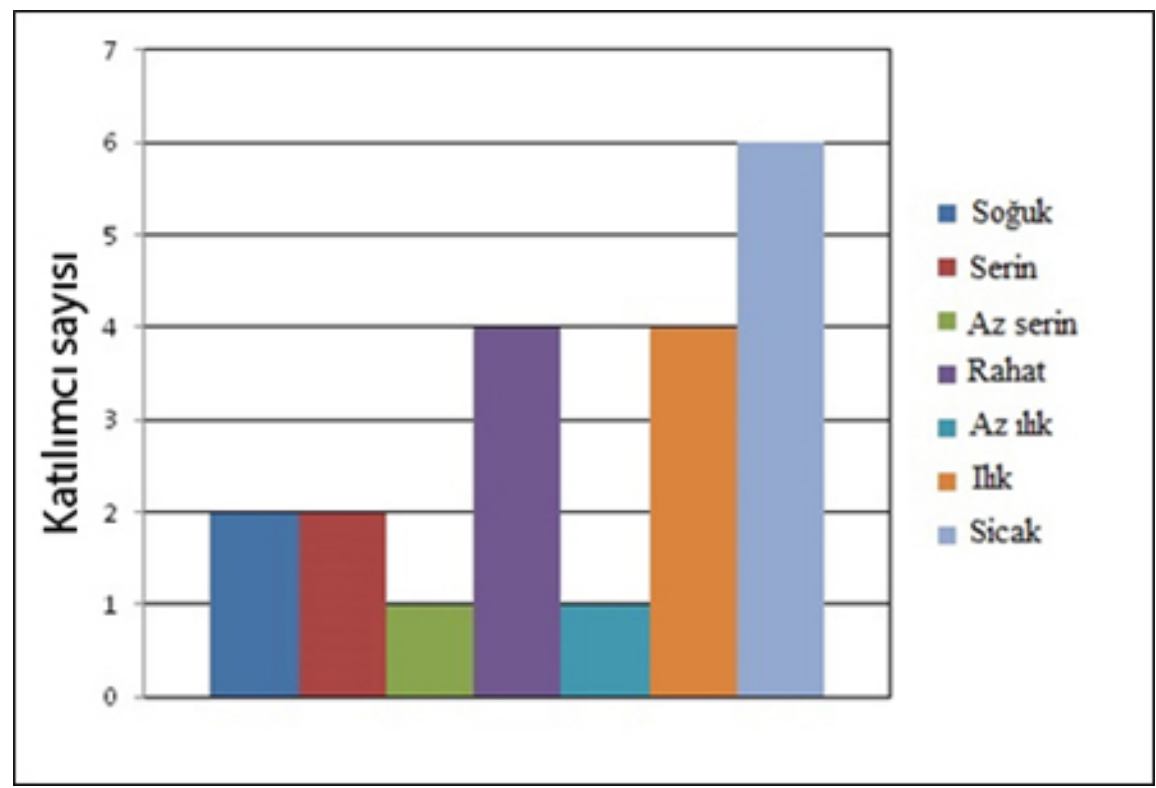

Şekil 4: Isıl hissiyata yönelik ölçek

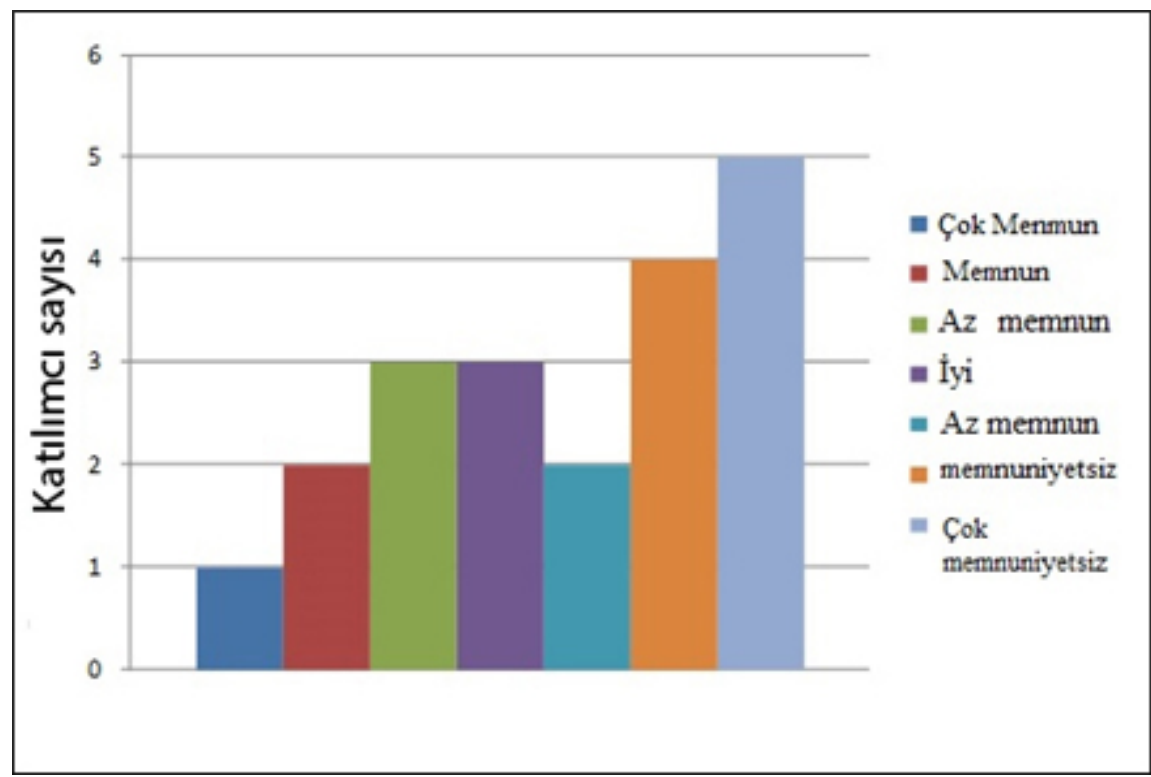

Şekil 5: Isıl koşullardan memnuniyet oranları

Tablo 5' de görüldüğü üzere, sınıftaki hava hareketi hızlarının yok denecek kadar az olması nedeniyle de ortamı sıcak olarak algılamaktadırlar. Ulugazi İlköğretim Okulu'nda mevcut pencere açıklık konumunun hava akımı ve hareketi göz önünde bulundurulmadan oluşturulduğu gözlenmiştir. Sınıfta öğrencilerin oturma pozisyonundaki yükseklikleri ve pencerenin açıklık yüksekliği arasındaki fark nedeniyle hava akımı bölgesi üst kısımlarda oluşmaktadır. Cevapların büyük çoğunluğunda ortamda hava hareketinin durgun olduğu, yalnızca \%25 oranında öğrenci koşullardan rahatsız olmadığını belirtmiştir. 
Tablo 5. Öğrencilerin havalandırma koşullarına yönelik algıları

\begin{tabular}{|c|c|c|c|c|c|c|c|}
\hline & $\begin{array}{c}(-3) \\
\text { Çok } \\
\text { rüzgârlı }\end{array}$ & $\begin{array}{c}(-2) \\
\text { Rüzgârlı }\end{array}$ & $\begin{array}{c}(-1) \\
\mathrm{Az} \\
\text { rüzgârlı }\end{array}$ & $\begin{array}{c}(0) \\
\text { Rahat }\end{array}$ & $\begin{array}{c}\text { (1) } \\
\text { durgun }\end{array}$ & $\begin{array}{c}(2) \\
\text { Durgun }\end{array}$ & $\begin{array}{c}\text { (3) } \\
\text { Çok } \\
\text { durgun }\end{array}$ \\
\hline Sınıf & 0 & 0 & $2(10 \%)$ & $5(25 \%)$ & 0 & $2(10 \%)$ & $11(55 \%)$ \\
\hline
\end{tabular}

$\mathrm{Bu}$ ölçek öğrencilerin mevcut havalandırma koşullarına yönelik nasıl bir değişiklik beklentisi içinde olduklarını göstermektedir. Tablo 6' da öğrencilerin havalandırma koşullarına yönelik beklentilerinin dağılımı görülmektedir.

Tablo 6. .Havalandırma koşullarına yönelik tercihler ve dağılımları

\begin{tabular}{|c|c|c|c|}
\hline & Daha çok hava akışı & Değişim İstenmiyor & Daha az hava akışı \\
\hline Sınıf & $14(70 \%)$ & $6(30 \%)$ & 0 \\
\hline
\end{tabular}

Yapı kabuğundan, özellikle de pencere doğramaları ve taşıyıcı sisteme denk gelen kısımlardan ısı kayıpları meydana gelebilmektedir. Bu kayıpları da önlemek amacıyla mayıs ayında genellikle hava ılıman ve yumuşak olmasına rağmen okulun hala aktif sistemle ısıtıldığı elde edilen faturalardan görülmektedir. Anket sonuçlarının da ortaya koyduğu üzere öğrencilerin iç ortam sıcaklığından memnuniyet hissetmedikleri gözlenmiştir. Ulugazi İlköğretim Okulu'nda ısıtma sisteminin uygun değer aralıkları ve sürelerinde işletilmemesinden ve doğal havalandırmanın etkin biçimde sağlanamamasından kaynaklanan yüksek sıcaklıklar enerji tüketimi ve ısıl konfor bağlamında problem yaratmaktadır. Ayrıca çocuklar ısı değişimine daha az toleransıı olduklarından, iç hava dağılımının ve hızlarının az olması, bunun yanında sıcaklık ve nem değerlerinin yüksekliği, öğrencilerin eğitim süreçlerinde göstermeleri gereken performansı olumsuz yönde etkilemektedir (Bayraktar, 2013,s.159). Bu da Ulugazi İlköğretim Okulu'nda ısıtma enerjisi kayıplarını azaltmanın yanı sıra öğrenciler için ısıl konfor şartlarının iyileştirilmesi gerekliliğini ortaya koymaktadır.

\section{ENERJi TASARRUFU BAĞLAMINDA OPTIMUM İKLIMSEL KONFOR SAĞLAMAYA YÖNELIK UYGULANABILLECEK YAKLAŞIMLAR}

Ulugazi İlköğretim Okulu'nda ısıtma sisteminin uygun değer aralıkları ve sürelerinde işletilmemesinden kaynaklanan yüksek sıcaklık dağılımları, enerji tüketimi ve ısıl konfor bağlamında problem yaratmaktadır. Bunun yanı sıra yapı kabuğundan, özellikle de pencere doğramaları ve taşıyıcı sisteme denk gelen kısımlardan ısı kayıpları meydana gelebilmektedir. Binadaki ısı kayıplarını azaltmanın yollarından birisi ısı köprüsünü azaltmak üzere yapı kabuğunda gerçekleştirilebilecek müdahalelerdir (Bull, Gupta, Mumovic, Kimpian, 2014,s.5; Rospi, Cardinale, Intini, Cardinale, 2015, s.16; Dimoudi ve Kostarela, 2009, s. 293). Mevcut tarihi okul yapısında planlı koruma kapsamında yapı kabuğunda ve mekanik sistemlerde enerji verimliliğini arttırmaya yönelik iyileştirme yaklaşımları ele alınmıştır. 


\subsection{Yapı Kabuğunda Gerçekleştirilebilecek Uygulamalar}

Ulugazi Okulu'nda ele alınan tarihi blokta ısı transferlerini en aza indirmek üzere tarihi çatıya yalıtım katmanı eklemek suretiyle enerji tasarrufu sağlama imkânı bulunmaktadır. Aynı uygulama yapı kabuğu için önerilmekle birlikte yapı kabuğunun özgünlüğünü bozmamak adına iç yüzeyde gerçekleştirilecek yalıtım uygulaması enerji verimliliği sağlamak için uygun bir seçenek olarak görülebilir. Yalıtım malzemesi direkt olarak yüzeye tatbik edilebilir ya da iç yüzey önünde ahşap yüzey konstrüksiyonu oluşturulup arası yalıtım malzemesi ile doldurulabilir (Place Hansen, 2018, s.22). En dış kısma da bir bitirme malzemesi uygulanabilir. Bir diğer yöntem ise içi yalıtımla dolu olan hazır alçı panellerin iç duvar yüzeylerine monte edilmesidir (Pickles ${ }^{1}, 2016$, s.14, Murgul, Pukhkal, 2015,s.896).

Zemine oturan döşeme ve toprak arasında sıcaklık farkına bağlı olarak gerçekleşen ısı transferlerinin yoğunluğu nedeniyle bu kısma yalıtım katmanı eklenmesi ısı kayıplarını azaltarak enerji verimliliğinin artışını sağlayacaktır. Fakat Ulugazi İlköğretim Okulu'nda bodrum kat ısıtılamamaktadır ve ısı kaçışları ara kat döşemesi ve bodrum hacmi arasında gerçekleşmektedir. Bu sebeple zemine oturan kısma yalıtım katmanı eklenmesi gereksiz bir uygulama olacaktır. Ayrıca bodrum katta yer alan 26 pencereden 22'si kapalı tutulmakta ve kullanılmamaktadır. Bu sebeple düşük oranda hava değişimi, hava hareketi hızı ve dağılımı oluşmaktadır. Bu kat depo, tuvalet ve kantin gibi yan işlevler için kullanılmaktadır. Sonuç olarak bu katın yalıtılmasıyla düşük havalandırma nedeniyle dışarıya atılamayan su buharı yalıtım yüzeyinde yoğuşarak tarihi yapı duvarında bozulmalara neden olabilecektir.

Zemin kat ısıtılmakta olduğundan, zemin kat döşemesine uygun kalınlıkta yalıtım katmanı eklenmesi ve özellikle zeminde yerden ısıtma sistemi alternatifinin uygulanmasıyla bodrum kat yönüne doğru ısı kayıpları engellenebilecektir. Zeminden ısıtma kanallarının eklenmesi tarihi yapıya ait yassı taş birimlerinde oluşabilecek tuz ve nem problemlerini azaltabilecektir. Çünkü tesisata ait kanallar taş birimlerini ısıttığında buradaki nemin buharlaşmasına ve yoğuşma problemlerinin azalmasına katkı sağlayacaktır. Koruma bağlamında yapıda herhangi bir değişim ya da tamamıyla kaldırma gibi müdahalelere başvurmama hassasiyeti ile döşemede yer alan taş katmanları profesyonel yöntemlerle yerinden kaldırılarak yerden ısıtma sistemi ve yalıtım katmanı yerleştirilmeli, Bu katmanlar üzerine tekrar orijinal döşeme katmanı yerleştirilerek yapının özgün döşeme konstrüksiyonu korunmalıdır (Pickles², 2016, s.12). Ancak, Enerji verimliliği sağlanmasına rağmen, yaklaşım uygulama zorluğu ve özgün malzemelerde gerçekleşebilecek zaiyat riski nedeniyle en son başvurulacak yöntemlerden biri olmalıdır.

Pencere hava sızdırmazlığının arttırıması tarihi yapılarda en az maliyetle enerji verimliliği sağlayan yaklaşımlardan birisidir. Ayrıca pencerelere yapılacak müdahaleler içerisinde bina görünüşünün değişimine az miktarda etkisi olurken kullanıcı ısıl konforunun geliştirilmesinde ve ısıtma enerjisinin azaltılmasında büyük miktarda katkı sağlayan bir yöntemdir. Hava sızdırmazlığının arttırılmasıyla pencerelerden etkiyen dış ortam gürültüsünün azaltılması sağlanırken dışarıdan etkiyen kirli havanın iç mekâna nüfus etmesi de engellenebilmektedir. Pickles'in 2016'da gerçekleştirdiği çalışmaya göre pencerelerde hava sızdırmazlığı sağlamaya yönelik müdahalelerle odayı ısıtmak için gereken enerji miktarını $\% 33$ ve $\% 50$ arasında düşürmek mümkün olabilmektedir.

Orijinal doku ve malzemeli pencere ve kapılar tarihi yapıların kimlik ve karakterine büyük bir katkıda bulunmaktadır. İlk yaklaşım bu bileşenleri kaldırmaktan ziyade 
korumaya yönelik olmalıdır. Buna bağlı olarak pencerelerde yapılacak müdahalelerle enerji verimliliğini arttırmaya yönelik iyileştirme yaklaşımlarında da, orijinal pencere bileşeninde minimum değişikliği gerektiren çözümlerin öncelikli olarak ele alınması gerekmektedir (Pracchi, Rosina, 2013, s.214).

Ulugazi ilköğretim okulu mevcut tarihi yapısının cephesinde konumlanan pencerelerde cam yüzeyler geniş ve yüksek olduğu için ısı kayıpları oluşmaktadır. Bu sebeple sınıflardan pencereler yoluyla dış ortama ısı kaçışlarını engellemek üzere pencerelerin performansını arttırmak gerekmektedir. Çift camlı pencere sistemleri tek camdan oluşan pencere sistemlerine nazaran daha etkili bir ısıl performansa sahiptir. Ancak Ulugazi İlköğretim Okulu'nda, mevcut pencerelerin çift katmanlı birimlerle değiştirilmesi görüntü ve doku değişimine neden olabilecek, doğrama kısımlarına çift camın yerleştirilmesi için daha kalın ahşap kasa ve kanat bileşimlerine intiyaç doğabilecektir. Tek camın ağırlığının 4 misline çıkabilen yeni cam sistemi açık konumdayken pencere kanadının dengelenmesinde sorun oluşturabilir. Bu sebeple ikinci katman halinde cam yüzey içeren bir ahşap pencere kanadı eklemek uygun bir seçenektir. Çünkü ikinci cam yeni bir kasa ve kanatla taşınacağından orijinal pencere sisteminde herhangi bir değişiklik yapılmasına gerek kalmayacaktır.

Araştırmada sabah ve öğleden sonra gerçekleştirilen hava akımı hız ölçümlerinde 36 ölçüm değerinin tümünün sıfır olduğu görülmüştür. Hava akımı hızı ve dağılımının söz konusu olmaması, öğrencilerin yüksek sıcaklık, nem ve yetersiz iç hava kalitesinden rahatsız olduğu bu sınıflarda kabul edilemez bir durumdur. İç hava akımı eksikliği öğrencilerin ve öğretmenlerin performanslarını olumsuz yönde etkilemekte, sağlıklarını bozmaktadır. Ulugazi İlköğretim Okulu'nda pencerelerin tasarımı hava akımı ve hareketini olumsuz biçimde etkilemektedir. Şekil 6' da incelenen sınıfta öğrencilerin oturma pozisyonundaki yükseklikleri ile pencere kanatlarının açıldığı kısım arasındaki fark görülmektedir. Ayrıca Şekil 7 'de öğrencilerin oturur ve ayakta pozisyonlarındaki yükseklikleri ve bu yüksekliğe göre çok daha yukarı seviyelerde oluşabilecek hava akımı alanı görülmektedir. Bu fiziksel koşulların öğrenciler üzerinde yarattığı memnuniyetsizlik durumu anket sonuçlarında da anlaşılabilmektedir.

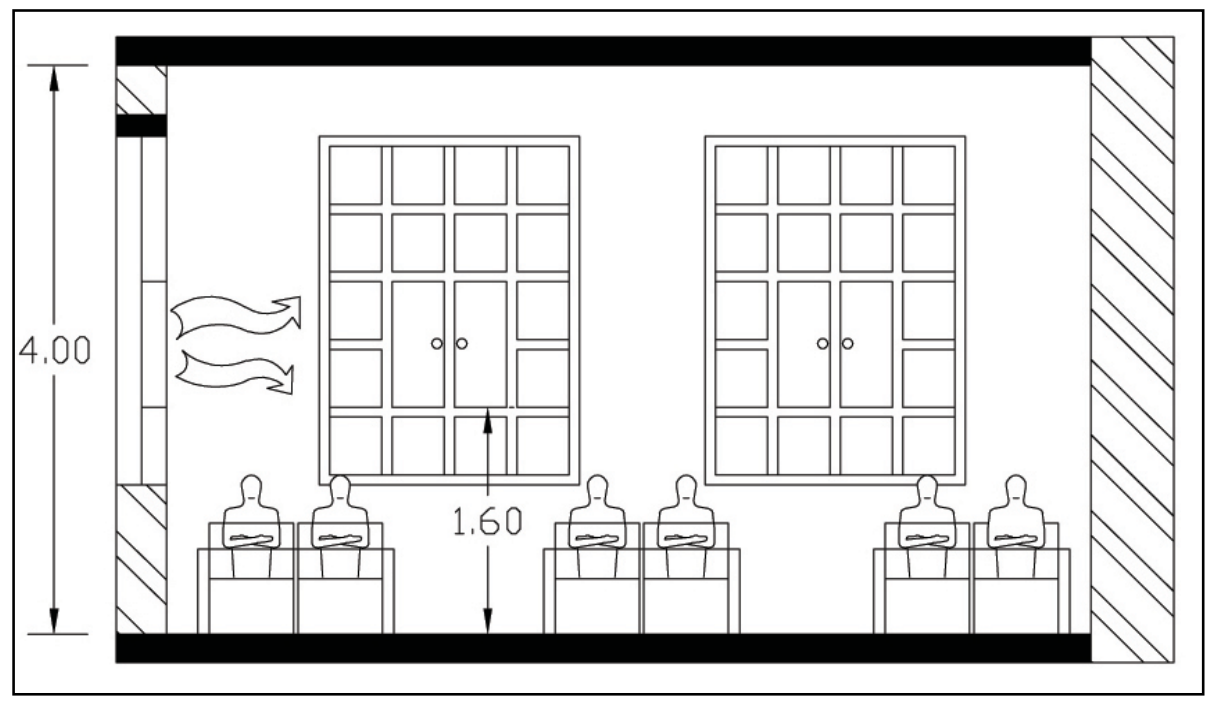

Şekil 6: İncelenen sınıfta pencere yükseklikleri 


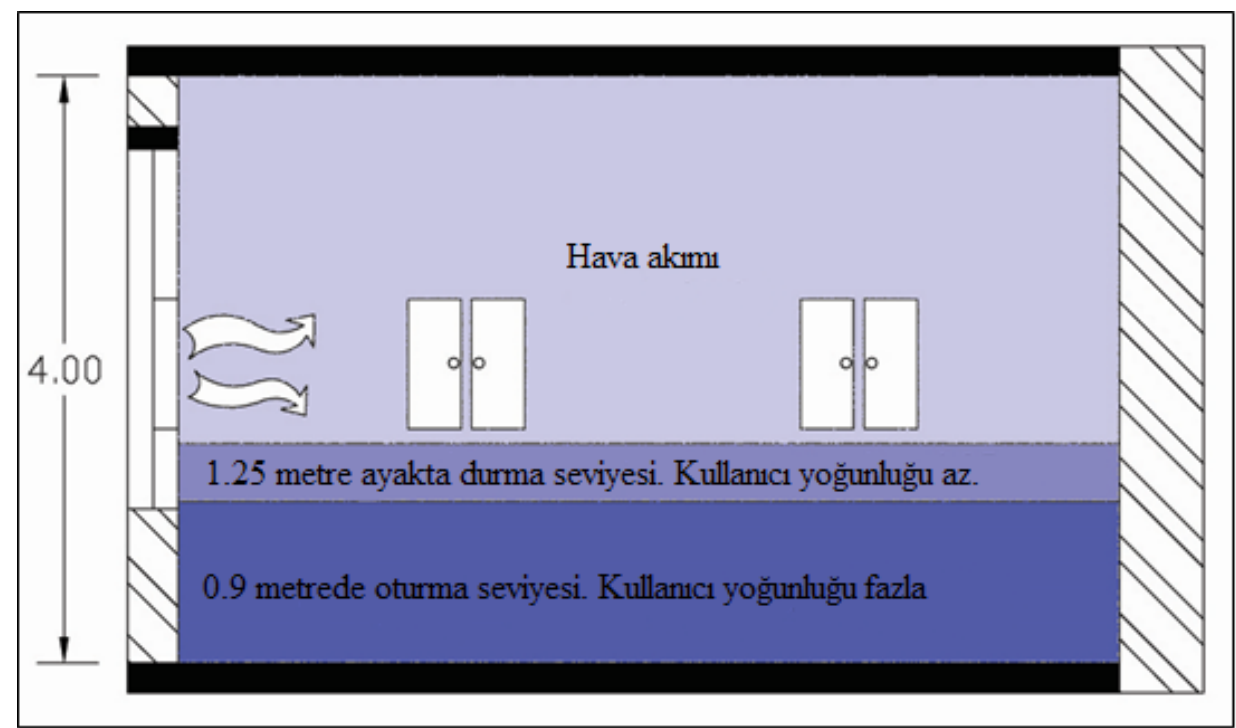

Şekil 7: İncelenen sınıflarda hava akımının düzeyleri

Öğrenciler pencereler açık olsa bile hava hareketinde herhangi bir fark hissetmediklerini belirtmişlerdir. Tarihi yapıda doğal havalandırma etkinliğinin olamaması için ana sebebin hava akımlarının öğrencilerin kullanım seviyelerinden yüksek kısımlarda gerçekleşmesi olduğu düşünülmekle beraber bu durumun simülasyon yoluyla ortaya konulması gerekmektedir. Anket sonuçları öğrencilerin tarihi binada yer alan sınıfta havalandırma koşullarından memnuniyetsizliklerini ortaya koymuştur.

Enerji verimliliğini arttırmak üzere gerçekleştirilen iyileştirme süreçlerinin parçası olarak ısıl konfor koşullarının optimum değer aralıklarına çekilmesi gerekmektedir. Ulugazi İlköğretim Okulu'nda bu koşulları sağlamak üzere pencere açıklık seviyesi öğrencilerin oturma pozisyonuna denk gelen yüksekliklere indirilmelidir. Tarihi yapıdaki pencere yüksekliklerinin fazla oluşu ortada yer alan açıklıkların alt kısımlara kaydırımasına imkân sunmaktadır. Kaydırma işlemiyle açıklık hizası yaklaşık olarak öğrencilerin ayakta durma pozisyonlarına denk gelecek ve hava akımlarından faydalanmalarını sağlayacaktır. Ayrıca oturma pozisyonlarında dahi hava akımlarının hız etkisini hissedebileceklerdir. Ancak bu yaklaşım cepheyi değiştirecek bir müdahale olduğundan tarihi yapılar için çoğunlukla tercih edilememektedir. Şekil 8 'de mevcut durum ve öneri pencere açıklık pozisyonlarında açıklıklardan etkiyen hava akımlarının seviye farkını ortaya koymaktadır. Ancak tarihi yapıların korunması sadece cephenin korunması anlamına gelmemektedir. Bu bağlamda kontrol sistemleriyle entegre edilmiş, uygun sayı ve tipte kanatlı tavan vantilatörleriyle iç hava hareketi hızı ve dağılımın arttıııması uygun bir yaklaşım olacaktır (Rosen,2009, s.4). 


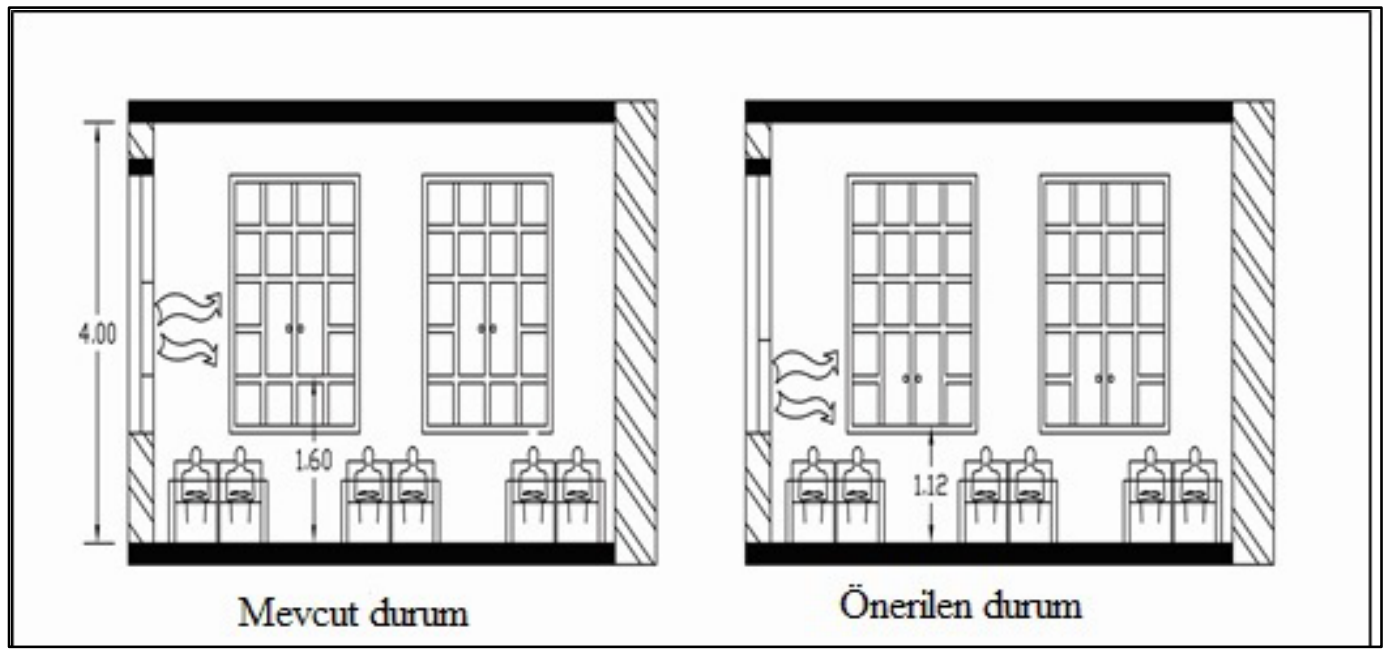

Şekil 8: Önerilen havalandırma şekli

Ulugazi İlköğretim Okulu'nda koridor ve kapılar ısı kayıplarına neden olmaktadır. Sınıflardan koridorlara doğru kapılar aracılığıyla ısı kaçışları gerçekleşmektedir. Öğrenciler teneffüslerde 5 dakika süreyle oyun alanlarına çıkmaktadır ve ana kapılar gün boyunca açık konumda durmaktadır. Okullarda enerji iyileştirme süreçlerinin bir parçası olarak, havalandırma yoluyla ısı kayıplarını azaltmak üzere hava sızdırmaz giriş lobisi ve rüzgârlık oluşturulması önerilebilir. Bina içinden dışarıya doğru hava akışlarını kontrol etmek amacıyla hava sızdırmaz giriş lobilerinde otomatik sensörlü kapı tipleri tercih edilmelidir. Şekil 9 giriş lobisini ve tarihi binada zemin kata eklenebilecek kapıları göstermektedir.

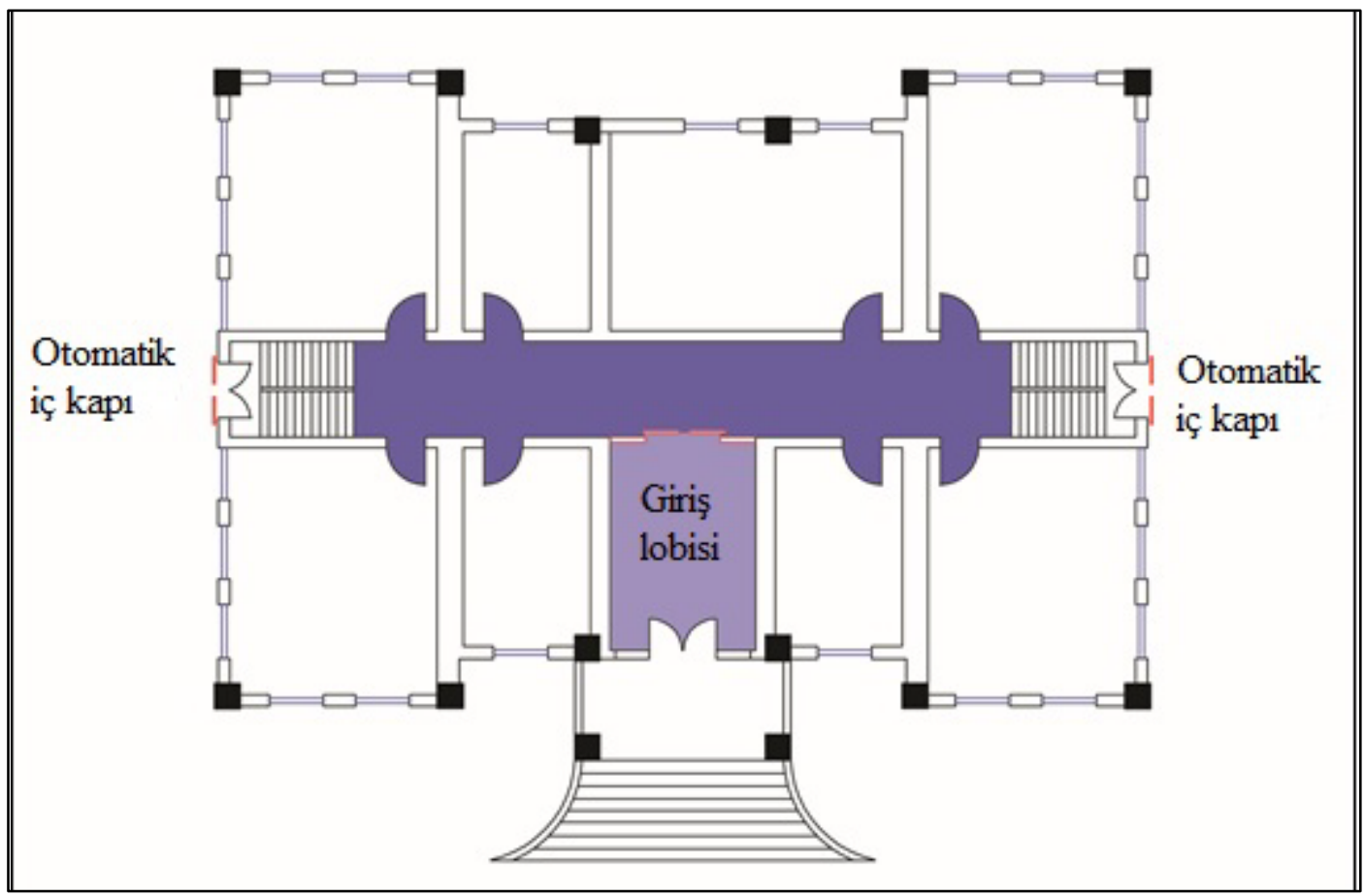

Şekil 9: Zemin kata eklenmiş olan giriş lobisi ve iç kapı 


\subsection{Mekanik Tesisatlarda Gerçekleştirilebilecek Uygulamalar}

Ulugazi okulunda Isıtma sistemi ile ilgili birçok sorun belirlenmiştir. Isıtma sisteminin temel sorunu herhangi bir sınır değer gözetilmeden, çocukların sıcak bir ortamda eğitim almaları adına sınıfların gerektiğinden fazla miktarda ısıtılmasıdır. Bu yaklaşım hem büyük enerji kaybına hem de çocuklar ve öğretmenlerin iklimsel koşullardan olumsuz yönde etkilenmelerine neden olmaktadır. Sınıfların optimum iklimsel konfor koşullarını sağlayan sıcaklıkları aşmayacak biçimde, belli zaman aralıklarında ısıtılması gerekmektedir. Sınıflarda iklimsel konfor koşullarını sağlayan bina kabuğu-ısıtma sisteminin işletme biçimi seçenekleri belirlenerek, minimum enerji tüketen ve en az yaşam dönemi maliyeti oluşturan alternatif belirlenmelidir (Manioğlu, 2002, s.27). Ayrıca ısıtma süreci ve miktarı dış iklimsel koşullar etkisinde değişim göstermelidir.

Konfor sıcaklığını ayarlamak üzere Adaptif konfor modelinin kullanımı enerji kazanımı sağlamakta, iç ortam konfor koşullarının optimum değer aralıklarına çekilmesini sağlamaktadır. Gereksinim duyulan iç operatif sıcaklık aralığı, aylık dış ortam sıcaklık koşullarına bağlı olarak belirlenir (Ashrae 2005, s.18). Bu modele göre gerekli sıcaklık dengesi için, ortalama dış ortam sıcaklığı, operatif sıcaklık, ortalama ışınımsal sıcaklık, sınıflardaki iç ortam sıcaklığı, vs. gibi iç ve dış çevresel değişkenlerin aldığı değerlerin günlük olarak hesaplanması gerekmektedir. Bu bağlamda hastane gibi büyük ölçekli yapılarda kullanılan, elektrik, su, sıcaklık, aydınlatma, bilgisayar ağı ve doğalgaz gibi unsurların yönetimine katkı sağlayan 'SCADA' benzeri bina otomasyon sistemleriyle (BAS) iklimsel parametrelerin kontrolünde büyük kolaylık elde etme potansiyeli vardır. Ancak okul gibi küçük ölçekli yapılar için söz konusu sistemler maliyetli olabilmektedir (Şener, 2016, s.884. Figueiredoa, Costa, 2012, s.88). Bina enerji yönetim sistemleri (BEMS) sistemleri ISı, nem, aydınlatma kontrolünü içeren çevresel kontrol ile boyler, zonlama, ve radyatör kontrolünün dahil olduğu mekanik kontrol sistemlerini barındırır ve enerji tüketim miktarlarını belirler. Büyük ölçekli yapılarda kaybedilen enerji miktarının azaltılmasına katkı sağlayan bu sistemler adaptif ısıl konfor modeline bağlı olarak gereken ısıl koşullara yönelik ısıl değerleri hesaplamak üzere otomatik olarak programlanabilmektedirler (Trend, 2010, s. 11). Tarihi binada, Isıtma sisteminin etkin şekilde kontrolünü sağlamak üzere 4 ana kontrol yaklaşımı gerçekleştirilebilir:

Adaptif modeline dayalı istenen sıcaklık değerinin elde edilmesi için adaptif ısıl konfor hesaplayıcısının yerleştirilmesi

Zonlarda kullanıcı olduğu durumlarda ısı tedarik etmek üzere için zamanlama şalterlerinin (switches) kurulması.

İdeal başlat/durdur kontrolünün kurulması ısıtmanın etkin bir şekilde sağlanmasına katkı sunacaktır. Mekanların optimum konfor sıcaklık değerlerine ulaşabilmesi için bir miktar zamana intiyaç vardır. Bu süre de dış hava koşullarına bağlıdır. "Bina enerji yönetim sistemleri" öğrenciler gelmeden sınıfları ısıtmak amacıyla dış hava koşullarına bağlı olarak merkezi ısıtma sisteminin çalışmaya başlaması için optimum süreyi belirleyen yeni bir teknolojiye göre işlem yapmaktadır. Benzer bir şekilde bu sistemler öğrenciler ayrılmadan önce kazanların kapatılması için ideal zamanı da belirleyebilirler. Isıl zonlarda ısıl kontrolleri arttırmak için radyatör vanaları eklenmesiyle, her kısım için gerekli sıcaklığa ulaşmak üzere ısı yayan radyatörler vasıtasıyla ortama verilen ısının kontrolünü sağlama imkânı bulunmaktadır.

Ulugazi Okulu'nda tüm bloklar etkin dağıtım sistemi olmayan merkezi ısıtma sistemi tarafından ısıtılmaktadır. Binalardaki tüm ısıl zonlar işlevlerin gerektirdiği farklı mikro iklimsel koşullar gözetilmeden aynı miktarda enerji tüketimi ve sıcaklık değerleriyle 
ısıtılmaktadır. Isıtma sisteminde aynı zamanda enerji tüketimini arttıran ciddi bir ısı kaybı problemi de mevcuttur. Bu sorunlar bağlamında enerji iyileştirme süreçlerinin ilk adımlarından biri her blok için ayrı merkezi ısıtma sistemi eklenmesidir. Her merkezi kazanın boyutu binanın gerçek ihtiyacını karşılayacak büyüklükte ve verimde olmalıdır. Eski ısıtma sisteminin onarılması ya da yenisi ile değiştirilmesi şeklinde iki yaklaşım maliyet ve verim açısından değerlendirilerek son karar verilmelidir. Merkezi ısıtma sisteminin verimini artırmak üzere yoğuşmalı boyler kullanımı iyi bir seçimdir. Yoğuşmalı boylerlerin çalışma prensibi atık gazlardan çıkan hissedilmeyen ısıyı yaymak için ikincil bir ısı dönüştürücü kullanmasıdır. Bu sayede enerji korunumu sağlanır, ısıtma sisteminin performansı geleneksel boylerlere göre yaklaşık \%10-12 oranında artış gösterir (Satyavadaa, 2018, s.121).

Tarihi binada farklı işleve sahip tüm mekânlar için farklı ısıtma rejimi uygulanmalıdır. Söz konusu yapıda, her ısıl zonun işlevine bağlı olarak, diğerlerinden farklı zamanlarda ve farklı sıcaklık değerlerinde ısıtılması gereği göz önüne alınmadan eşit sürelerde, benzer sıcaklık derecelerinde ısıtıldığı belirlenmiştir. Benzer ısıtma ihtiyaçlarına sahip alanların bağımsız biçimde farklı ısıtma rejimleriyle ısıtılması, okullarda enerji verimliliğini geliştirmek adına katkı sağlamaktadır.

Tarihi binadaki zemin ve birinci kat ısıtılmaktadır ve bu iki kattaki tüm alanlar sınıflar, öğretmen ve yönetici odaları ve sahne olmak üzere üç ana ısıl bölge olarak sınıflandırılabilir. Her bölge boyutuna ve intiyaçlarına göre ısıtılmalıdır. Örneğin konferans salonu tüm hacmin ısınması beklenmeden radyatörlerin kapatılabileceği bir mekândır. Bu kısımlar hızlı ısınıp, hızlı soğuması gereken kısımlardır. Ayrıca sınıflarla, öğretmen ve yönetici odalarındaki ısıl gereksinimler de farklıdır. Çünkü sınıflar hacim olarak daha büyüktür ve daha fazla sayıda kullanıcı barındırmaktadır. Üstelik kullanıcı olarak yetişkinlerden farklı adaptasyon biçimleri olan öğrencilerin sayıca fazla olduğu mekânlardır ve gereksinimlerin onların önceliklerine göre belirlenmesi gerekmektedir. Burada kullanılan ve iç ısıl kazanımlara katkısı olan aydınlatma ekipmanları ve diğer bilgisayar gibi ekipmanların katkısı da göz ardı edilmemelidir.

Ayrıca ısıtma tesisatına ait kanalların ve sıcak su deposunun yalıtılarak Isı sızdırmazlığının sağlanması da önemli bir enerji iyileştirme stratejisidir.

\section{DEĞERLENDİRME VE SONUÇ}

$\mathrm{Bu}$ araştırmanın amacı Ulugazi İlkokulu'nda enerji verimliliğini ve ısıl konforu geliştirmeye katkı sağlayabilecek ölçütlerin ve yaklaşımların belirlenmesidir.

Ele alınan okul örneği yapı tipolojisi, enerji tüketimi miktarı ve biçimi, sahip olduğu ısıl ve görsel konfor koşulları bağlamında incelenmiştir. Yapılan ölçüm ve anket çalışmaları sonucunda, iklimsel konfor koşullarının istenen düzeylerde gerçekleşmediği görülmüştür. Ayrıca faturalar yoluyla aylık enerji tüketimleri incelendiğinde bahar döneminde dahi ısıtma için enerji tüketildiği, bazı aylarda tüketimin dramatik biçimde artış gösterdiği görülmüştür. Gaz tüketimi kış döneminde oldukça yüksektir. Özellikle gaz tüketim miktarının Ekim 2014'te 0 değerinden Kasım 2014'te 29660 kW/h miktarına çıktığı görülmüştür. Sadece bir ay süresince gaz tüketimindeki bu büyük fark ve Şubat'taki tüketim (26024 kW/h) miktarının daha düşük sıcaklıklardaki dış koşullara rağmen Kasım'daki tüketim miktarından $(29660 \mathrm{~kW} / \mathrm{h})$ daha düşük olması gibi bulgular okuldaki ısıtma sisteminin verimliliği ya da işletimindeki sorunlara işaret etmiştir. Bu bağlamda tarihi yapı bloku için enerji kayıplarının olabileceği problemli kısımlar belirlenerek enerji verimliliğini arttırmaya yönelik stratejileri önerilmiştir. 
Tarihi yapının özgün değerini korumak adına uygulanabilecek stratejiler, özellikle de yapı kabuğu için gerçekleştirilebilecek uygulamalar kısıtıdır. Bu yaklaşımlar yapı kabuğunda ve mekanik sistemlerde gerçekleştirilebilecek iyileştirmeler olarak ayrı başlıklar altında sınırlandırılarak incelenmiştir. Yapı kabuğunda gerçekleştirilebilecek ilk yaklaşım çatı, duvar ve ısı kaçışı olan döşemelerde ısı yalıtımı uygulamalarıdır. Tarihi yapılarda cephe özelliklerinin bozulmaması amacıyla dış yüzey yerine iç yüzeylerde ısı, nem yalıtım uygulaması yapılması önerilmektedir. Yapılarda ısı yalıtım uygulamalarının dış yüzeyde uygulanması ısı kaçışlarının engellenmesi adına en doğru yaklaşım olmakla birlikte bu uygulamanın yapı cephesinin özgünlüğüne olumsuz etkisi nedeniyle tarihi yapılarda öncelikli olarak tercih edilmemektedir. Ayrıca cam tiplerinin yüksek ısıl performansa ve sızdırmazlığa sahip çok katmanlı ve düşük ısı geçirme katsayısına sahip (U değeri, $\mathrm{W} / \mathrm{m}^{2} \mathrm{~K}$ ) cam ve çerçeve sistemleriyle değiştirilmesi, koridor ve girişlerdeki mevcut kapıların sızdırmazlık özelliğine sahip kapılarla değiştirilmesi de enerji verimliliğinin arttırımasına katkı sağlayacaktır. Ancak bu yaklaşımda da özgün pencere sisteminin özelliklerine olumsuz etkide bulunacak düzeyde müdahale yapılmamasına özen gösterilmelidir. Bu sebeple dıştan görüntüyü bozmayan ancak iç kısma eklenen ek bir kanatla ısı korunumu sağlamak mümkün olabilecektir.

Mekanik sistemlerde uygulanabilecek önde gelen iyileştirme stratejilerinden birisi 'bina enerji yönetim sistemlerinin' (BEMS) kullanılmasıdır. BEMS okullarda mikro iklimsel kontrolleri arttırmak için tercih edilen bir uygulamadır. $\mathrm{Bu}$ sistemler enerji performansının sürekli olarak gözlemlenerek doğru bir şekilde yönetilebilmesi için tasarlandığından dış ortam koşullarına bağlı olarak ısıtma intiyacı doğru biçimde belirlenebilecek, gereksiz enerji kayıpları önlenebilecektir. Isıtma için başlangıç ve kapanma sürelerinin dış iklimsel koşullara ve iç iklimsel konfor değerlerine göre ayarlanmasını sağlayan kontrol mekanizmalarının eklenmesiyle enerji tüketimleri azaltılabilecek, optimum iklimsel konfor koşulları sağlanabilecektir.

Tarihi ve tarihi niteliğe sahip olmayan her iki yapı için tek bir ısıtma sistemi yerine ayrı, intiyaca uygun merkezi yoğuşmalı boyler sistemlerinin seçilmesi ile ısıtma sistemlerinden elde edilen verim artacaktır. Ayrıca yoğuşmalı kazanların çalışma prensibine bağı olarak atık gazlardan çıkan hissedilmeyen ısı da kullanıldığından ısıtma sisteminin performansı yükselecektir.

Enerji tüketimin azaltılması hem öğrencilerin uygun iklimsel ve görsel koşullarda eğitim hayatlarını sürdürebilmeleri, hem de yapının tanınma süreci, mevcut fiziksel koşulların belirlenmesi, kullanıcıların iklimsel koşullardan etkilenme biçimlerinin ortaya konulması ve gerçekçi verilerle doğru kararların verilmesi açısından önemlidir. Çalışmada enerji tüketiminin gerçekleşebileceği problemli kısımlar, yerinde gözlem sonucu elde edilen veriler ve aylık doğalgaz enerji tüketimini gösteren faturalar yoluyla değerlendirilmiştir. Ancak en doğru yaklaşım hasarsız testler kapsamındaki IR görüntüleme yöntemiyle yapı kabuğundaki, enerji kayıplarının, ısı köprülerinin ve bozulmalarının belirlenerek daha gerçekçi verilerin elde edilerek müdahaleye yönelik stratejilerin belirlenmesidir( Bayraktar, Kishalı, 2018, S. 87-89).

Ulugazi ilköğretim Okulu için gerçekleştirilen çalışma geliştirilerek Türkiye'de benzer niteliklere ve bağlama sahip yapılar için referans özelliği gösterebilir ve başka okul yapıları için de uygulanabilir. Ancak her yapı tipolojisi, kullanıcıları ve bulunduğu çevreyle farklı etkileşimler içerisinde bulunduğundan enerji tüketim, karbon salınım, görsel, iklimsel ve akustik konfor koşulları da farklı olacaktır. Bu sebeple iyileştirme stratejilerinin yapı özelinde belirlenmesi gerekmektedir. Mekanik ve elektrik sistemlerinde önerilecek yaklaşımlar uzmanlık gerektirdiğinden displinler arası çalışmalarla yürütülmelidir. Bu çalışma kapsamında ele alınmamakla berarber önerilen stratejilerin getirdiği katkı düzeylerinin belirlenmesi ve karşılaştırma yapılarak optimum 
seçeneklerin belirlenmesi amacıyla benzetişim çalışmalarının yürütülmesi diğer önemli bir adımı oluşturmaktadır.

\section{KAYNAKLAR}

Ascione, F., Biancoa, N., Masia, R. F., Rossib, F., Vanoli, G. P., Energy Retrofit Of An Educational Building In The Ancient Center Of Benevento. Feasibility Study Of Energy Savings And Respect Of Thehistorical Value, Energy and Buildings 95, 2015, ss. 172183.

ASHRAE Handbook Fundamentals I-P Edition, 'Chapter8- Thermal Comfort', Supported by ASHRAE Research, American Society of Heating, Refrigerating and AirConditioning Engneers, Inc, 2005, ss 1-29.

Bayraktar N. T. "Evaluation of Natural Ventilation Efficiency in School Buildings in the Context of Thermal Comfort and Interior Air Quality, 10th Anniversary International conference "Standardization and Related Activities - A Means of International and Balkan Collaboration. 2013, Sozopol, Bulgaria,, 1, ss. 157-163.

Bayraktar N. T., Kishalı E., (2017). Tarihi Yapılarda Hasarsız Testler Aracılıgıyla Önleyici Korumanın Saglanması: Kocaeli Ulugazi Ilkokulu Örneg,. Mimarist, 60, ss. 8590.

Berardi, U., Building Energy Consumption In Us, Eu, And Brıc Countries, International Conference on Sustainable Design, Engineering and Construction, Procedia Engineering 118, 2015, ss. $128-136$.

Building Energy Management, Strategic Planning For Education, The fast-track guide to reducing energy and carbon emissions in an educational environment, Trend Control Systems Limited, Sussex, 2010, ss.1-16.

Bull,J, Gupta,A. Mumovic, D., Kimpian,J. ,Life Cycle Cost And Carbon Footprint Of Energy Efficient Refurbishments To 20th Century UK School Buildings, International Journal of Sustainable Built Environment (2014) 3,ss. 1-17.

Dimoudi, A., Kostarela, P., Energy Monitoring And Conservation Potential In School Buildings In The CO Climatic Zone Of Greece, Renewable Energy 34, 2009 ss.289296.

Fanger P. O., Assessment Of Man's Thermal Comfort in Practice British Journal Of Industrial Medicine, 1973, 30, ss. 313-324.

Figueiredoa, J., Costa, J., A SCADA System For Energy Management In Intelligent Buildings, A Energy and Buildings 49,2012, ss. 85-98.

Manioğlu, G.,, Bina Kabuğu Ve Isıtma Sistemi İşletme Biçiminin Ekonomik Analizi, itü dergisi/a, mimarlık, planlama, tasarım, Cilt:1 Sayı:1 Eylül 2002, ss. 21-29. 
Milone, D., Peria, G., Pitruzzella, S., Rizzoa, G., Are The Best Available Technologies The Only Viable For Energy Interventions In Historical Buildings?, Energy and Buildings 95, 2015, ss.39-46.

Murgul, V., Pukhkal, V, Saving the Architectural Appearance of the Historical Buildings due to Heat Insulation of their External Walls, International Scientific Conference Urban Civil Engineering and Municipal Facilities, SPbUCEMF-2015, Procedia Engineering 117, 2015, ss. $891-899$.

Pickles, D ${ }^{1}$., Energy Efficiency And Historic Buildings: Early Cavity Walls, 2016, English Heritage, ss. 5-30.

Pickles, D²., Energy Efficiency And Historic Buildings: Insulating Solid Ground Floors, 2016, English Heritage, ss. 1-22.

Place Hansen, E.J., Wittchen, K.B., Energy Savings Due To Internal Façade Insulation In Historic Buildings, EEHB 2018, The third international conference on energy efficency in historic buildings,ss. 22-31.

Pracchi, V., Rosina, E, Protecting Historical Buildings is Not Only A Question Of Respecting Their Appearance, 3rd European workshop on cultural heritage preservation, EWCHP, 2013, ss. 211-217.

Rosen M.A., Development of an Enhanced Ceiling Fan: An Engineering Design Case Study Highlighting Health, Safety and the Environment, Minerva Canada Case Study on Development of an Enhanced Ceiling Fan, Minerva Canada 2009, ss.1-26.

Rospi, G., Cardinale, N., Intini, F., Cardinale, T.,Analysis of energy consumption of different typologies of school buildings in the city of Matera (Southern Italy), Energy Procedia 82, 2015,ss.512 - 518.

Satyavadaa, H., Baldib, S., Monitoring Energy Efficiency Of Condensing Boilers Via Hybrid First-Principle Modelling And Estimation, Energy, Volume142, 1 January 2018,ss. 121-129.

Somyürek, U., Sağlık Tesislerinde Enerji Verimliliği Analizinde Enerji Yoğunluğunun Kullanılması İle Yeni Yaklaşımlar Ve Yapılan Enerji Verimliliği Uygulamalarının Değerlendirilmesi.Rapor. 2017. Denizli Kamu Hastaneleri Birliği Genel Sekreterliği.

Şener, M, Cumhuriyetin Illk Yıllarında Ziraat Bankası Ve Iş Bankası Hizmet Binaları: Milli Mimarlık Ve Banka Yapıları, Tarih ve Uygarlık-İstanbul Dergisi, 2016, Doğu Kitabevi, ss. 205-227.

Şener, M., Kılıç, F., A Multidisciplinary Overview of Integrated Design and Energy Efficiency Based Applications in Hospital Constructions of Turkey, CESB 16 - Central Europe towards Sustainable Building 2016 Innovations for Sustainable Future, Electronic Proceedings, 1st edition, 22-24 June 2016, Prague, ss.881-888.

Trachte S., Herde A. D., Sustainable Refurbishments, School Buildings: A Guide for Designers and Planners, 1st ed., International Energy Agency, London, 2015, ss. 1332.

URLhttp://ulugazi.meb.k12.tr/meb_iys_dosyalar/41/01/315404/icerikler/okulumuzuntari hcesi_274194.html 